\title{
Atiśa の如来蔵思想
}

\author{
一その典拠と大中一
}

\section{宮 崎泉}

\section{はじめに}

これまで既に数多くの Atiśa（982-1054, Dīpaṃkaraśrīinn̄āna とも）に関する研究の蓄 積があるが, Atiśaの思想的立場についてはなお多様な議論があり, 多くの点で検 討の余地が残る ${ }^{1)}$. その背景には, チベット仏教の展開の中で Atiśa の思想的立場 に対する理解が変化したこと ${ }^{2)}$ があるのかもしれない. また, Atiśa が思想家とい うより宗教家であり ${ }^{3)}$ ，思想的な点に関する記述が簡潔にすぎるということも理 由に挙げられるであろう。つまり, Atiśaの力点は, 我々が興味を持つことと違う 所にあり，それこそがAtiśa の最大の特徴であると言ってよいが, 一方で我々の 興味がある点は不明瞭なことも多い.しかしまず，時にテキストに問題が残るよ うな場合も含め ${ }^{4)}$, Atiśa 著として残る論書をテキストそのものから丁寧に検討し 分析していくことが求められよう. Atiśaの如来蔵思想もまた, 理解の仕方によっ てその思想的立場を全く異なった所に位置づけることになるため，検討の余地が 残る点の中でも特に重要なものの一つと言える。ここではAtiśa 自身の著作だけ を用いて，その如来蔵思想がどのようなものかを検討してみたい.

Atiśa が自身の著書の中で如来蔵に言及し，そこで「大中」（dbu ma chen po）の語 を使うことはこれまでにも指摘されてきた5). 両者を関連づけて理解し, Atiśa が 如来蔵の実在性を主張しているとするなら, Atiśaの思想的立場はもはや中観派と 言うことはできないであろう。しかし，Kamalaśīla も『中観光明論』の中に一乗 思想を説き，種性の非実在性を主張することが知られている ${ }^{6)}$ 。とすれば，種性 の無区別が他の後期中観派の論師の主張であっても問題がない可能性もあろう. そこで本稿では, Atiśa が説く如来蔵について，例によって簡略な Atiśa の記述を 特に典拠に注意しながらまとめ, その性格を明らかにしたい.さらに，関説され る「大中」の語も改めて確認しておこう.

Atiśa は数多くの小品を残しているが, 如来蔵の語を出すことは少なく, 『菩提 
道灯細注』(Bodhimārgadīpa-pañjikā, D 3948, P 5344, 以下『細注』あるいはBMDP) と『中 観優婆提舎開宝筮』（Ratnakarandododghāta-nāma-Madhyamakopadeśa, D 3930, P 5325）に限 られる。『中観優婆提舎開宝筮』は, 自性戒の説明の中に, 一切衆生が一種性であ り, 如来蔵を有し, 大乗種姓を有するが, 四種の過失によって覆われていると極 めて簡略に述べるだけである7)。この自性戒の解説は『菩薩地』とも一致せず, それ以上論ずることが難しい. そのため，ここでは「大中」の語もあわせて出る 『細注』の一節だけを取り上げることにしょう。

\section{1.『細注』に如来蔵の語が出る文脈}

『菩提道灯細注』は，大乗仏教に進むべき者の資質を明かした後，発心受戒から 始め, 戒定慧の三学の順に大乗の実践を解説する論書である。その中でAtiśa は 菩提心の解説を終えた後, 戒に話が移るにあたり, 次の『菩提道灯』本頌を引く.

七衆の別解脱律儀（prātimokșa-samvvara）の一つを常に備えた者は菩薩律儀の可能性があ るが, 他はそうではない.（BMDP, D 258a5-6, P 297b5-6=BPP 79-82）

これは, 菩薩律儀を受けるにあたって, いわゆる小乗の戒律律儀が必要なこと を説くものである. Atiśa は, 直接の師である Bodhibhadra を通じ, 菩薩戒の理解 を『菩薩地』に依っている。『菩薩地』では, 菩薩戒は律儀戒, 摂善法戒, 饒益有 情戒の三つに区分され，律儀戒が別解脱律儀に当たる. そのため，この偈自体が 後期中観派にとって問題になることはないが, 既に Atiśa 自身が解説した『菩提 道灯』の偈頌と齟齙があるように見えるため, この後すぐに反論がある. その議 論の中でさらに話が展開し,「如来蔵」あるいは「一乗」の話に発展することにな る. 反論は次のようなものである.

〔反論〕これに対して言う。「君は最初に『[自身の心相続に属する苦しみによって, 他者 の全ての苦しみを完全になくそうとする, 〕それが最高の人である. その最高の悟りを求 めている優れた者達に対して〔師匠らが説いた正しい手段を説明しよう.〕』(BPP[17-]2022[-24]）と言わなかったか. またここでこのように述べたのはどういうことか.」8) (BMDP, D 258a6-7, P 297b6-7)

これは, 『菩提道灯』に既に人が三者に分類され, その中の他者の全ての苦しみ をなくそうとする最高の者に対して大乗の実践が説かれているにもかかわらず, ここで菩薩戒を受けるに当たって新たに限定を加える意図を問うているのである. それに対して, Atiśa は三つの観点から別解脱律儀の必要性を説明する。（1）菩 
薩は，殺生などを離れていて，清浄であること，（2）種性に区別はなく，誰もが 仏説の根本である別解脱律儀を第一とすべきであること，（3）実践の順序として も, 別解脱律儀が先行すること，の三つである。この中で本稿の主題に関わる如 来蔵と大中の語が出るのは第二の項目だけであるが，三つの観点は，相互に関連 しており，完全に独立しているわけではない。 また，どのような文脈にそれらの 語が出るかを見る必要があるため，本題に入る前にまず全体の流れをまとめてお こう.

第一点目について, Atiśa は,

〔答論〕答える，その通りである。前は清浄ではない依処を設定したのであり，これは清 浄な依処として認めているのである。（BMDP, D 258a7, P 297b7）

と答え, さらに, Bodhibhadraの『菩薩律儀二十頌細注』を引用しながら, 菩薩律 儀を受ける器となるには別解脱律儀が必要なことを説く． Bodhibhadraの引用に は，まず別解脱律儀が菩薩律儀の支分であることが説かれ，そして，殺生などを 離れる別な儀軌は存在せず，殺生などすら離れていない者が9）菩薩律儀を受ける 器になることはないという形で別解脱律儀の必要性が説明される．続いて Atiśa は, 別解脱律儀がなく殺生などを離れていない者に菩薩律儀があり得ないことを, 菩薩にとって殺生などが根本罪過であることから説明する。一方で，これまでの 生の中で既に大乗を反復修習した者は本質的に罪を犯さないため, 初めから菩薩 律儀を受けてもよいとも言う.

このように，ここまでは，大乗の実践に進むにあたってまず他者の全ての苦し みをなくそうとすることが必要であり，さらに，出家戒であれ，在家戒であれ， 別解脱律儀のいずれかを受けていることが求められる，というように，次々に限 定が加わる方向で説明されている，そのため，大乗の実践が一見，一部の者に限

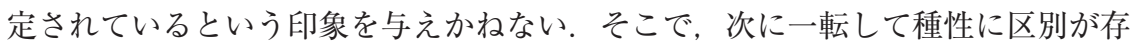
在せず，ただ一つであることが述べられることになったと思われる．種性に区別 がないことは，経典と論書が教証とされ，さらに，三つの有情のグループ (sattvarâsii）と五性の区別が一時的なものであることから説明される，最後に，種性はた だ一つであって，優是華のように希有な化身によって説かれた仏説が別解脱律儀 に依拠しているため，まず別解脱律儀が説かれたのであるから，それを第一とす べきであると言う。この箇所に, 如来蔵と大中の語が出るので, 後に詳述しょう. 最後に, 実践の順序としても, 別解脱律儀が先に必要であると言う。この点は, 
これまでの議論から明らかであるように思われるが, 改めて実践の順序とも一致 することがごく簡単に確認される。 そして, 結びとして

それ故に，本頌に「可能性はあるが，他はそうではない.」（BPP 82）というのも, 正し く説かれていることになろう。（BMDP, D 259b2, P 299a4）

と述べこの一節を閉じている.

\section{2. 種性に区別がないこととその典拠}

さて，このような文脈の中で，Atiśa は次のように述べ，種性に区別がないこと を理由とする議論を始める。

また，大乗の大中（theg pa chen po dbu ma chen po）の教義（grub mtha'）をより堅固にし たならば, 大乗の器でない者は全く存在しない. 全ての有情はただ一つの種性を持ち, 「如来蔵をもつのである.」10）と〔説かれ，そして〕…… (BMDP, D 258b5-6, P 298a6-7)

ここに「大中」の語も「如来蔵」の語も同時に出る。そして，この「如来蔵をも つのである」という複数の可能性が考えられる経典の引用（1）の後, さらに経典 と論書の引用が続く．どれも書名は明記されないが, 順に挙げれば次の通りであ る.（2）経 (出典未詳)，（3）『真実摂経』(Sarvatathāgatatattvasamgraha)，（4）Āryadeva 著『四百論』(Catuhśataka）V-10，（5）Maitreya 著『現観荘巌論』(Abhisamayālaṃkāra) I-39ab，（6）Nāgārjuna 著『無譬讚』（Niraupamyastava）k. 21 であり，（1）と合わせ て計六つである. 経典の引用（2）は出典未詳であるが, 後期仏教の論書にしばし ば引かれ，Advayavajraの『真実宝環』（Tattvaratnāvalī）からサンスクリットが知ら れるものであり ${ }^{11)}$ ，「全ての者が仏陀になるであろう」と説く．『真実捸経』の引 用（3）は「器であるかどうかの考察をしない」ことを説き12), これも種性の区 別をしない方向のように見える。しかしながら, その後の論書の引用では, 同じ 法界の無区別を根拠とした，（5）『現観荘厳論』の種性の無区別と（6）『無譬讚』 の乗の無区別の前に，(4）『四百論』が引かれている点に充分注意が必要である. すなわち，偈頌の後半は『四百論』に一致しないものの，そこには，

何であれ，ある者に先に好むものがあれば，何でもその者のために実行すべきである. 正法の器でないものは全く存在しないのである。（BMDP, D 258b7-259a1, P 298b1-2）

と説かれ，単に種性に区別がないと言われているのではなく，究極的には乗は大 
乗一つしかないとしても, 大乗に導くという目的ではあらゆるものが認められて いるからである ${ }^{13)}$. そして, この点が次の話にも繫がっていく.

次は瑜伽行派からのものと考えられる反論である.

〔反論〕そうだとすると, 経の中に, 有情のグループが三つと説かれ, 山の類 (rdo’i rigs) に喻えられている ${ }^{14)}$ のはどういうことか. また，有情の種性が五種である ${ }^{15)}$ と説明さ れるのはどういうことか. (BMDP, D 259a2-3, P 298b4-5)

これに対して，Atiśaは一応この区別を認めるが，それは「一時的なもの」(re źig pa, *tāvat-kālika) であるとする。そして, Suvarṇadvīpaの言葉を引きながら，「法性 種性」(chos ñid kyi rigs can) と「習所成種性」(sgrub pa’i rigs can) という二つの種性 の分類を挙げ16)，「習所成種性」としては種性の区別はあるが，「法性種性を主題 とすれば，区別は全くない」（D 259a4, P 298b6）と言う。そして，種性の区別がな いことに基づいて, 大乗に進む者にも別解脱律儀が必要であるという話に繫がっ ていく，その理由を, 紙幅の都合上, 要点だけまとめて紹介すれば, 次の通りで ある。三身のうち，受用身は十地の菩薩の対象にしかならないので，十地の菩薩 以外は化身からの説法を聞くほかないが，化身は優曇華の如く希有なものである から, その仏説も希有なものである. そして仏説は, 別解脱律儀が存在する限り 存在し，それに依拠しているため，別解脱律儀が第一に説かれたのであり，種性 に区別はないので，賢者は皆必ずそれを第一とすべきである，と述べ，別解脱律 儀の必要性を強調している.

\section{Atiśa の著作における「大中」の意味}

なお，前述の通り，本稿で扱ったテキストの中に「大中」という表現が出るが， 筆者が以前『細注』の別の箇所を扱って論じたのと同様に ${ }^{17)}$, ここでも大中は瑜 伽行派より優れた立場としての中観派を意味していると考えられよう。この箇所 でAtiśa は，法性種性と習所成種性という二つの種性の分類を出すが，三つの衆 生のグループや五性は習所成種性の意図であり，「一時的なもの」にすぎず, 法性 種性という観点からは, 種性に区別はなく種性はただ一つであると言う。そして, 三つの衆生のグループや五性を区別するのは, 瑜伽行派の立場と考えられるから である。このように, Atiśaの著作では, 大中は瑜伽行派と対比させた単なる中観 派の立場と一貫して理解してよいように思われる ${ }^{18)}$. 


\section{むすび}

以上のように，テキストの読みを二箇所訂正した上で ${ }^{19)}$, 如来蔵という語が出 る文脈とその典拠を確認した。 もちろんこれは如来蔵そのものを解説するもので はない。また，Atiśaの説明は要点を記すだけなので，仮にAtiśa が如来蔵に関す る著作を著して解説すれば違ったものになったかもしれない. しかし, 少なくと もこの『菩提道灯細注』の一節は, Kamalaś11a 等の後期中観派の一乗思想の延長 線上に理解できるものと考えられる。『菩提道灯細注』には，如来蔵の実在は主張 されず，種性に区別がないことだけが説かれ，その典拠も，特に論書は，『現観荘 厳論』も引かれるものの, 『四百論』『無譬讚』という中観論書が挙げられるから である。また，本稿で取り上げた箇所に出る「大中」（dbu ma chen po）という語は, 以前拙稿で指摘したのと同様に，瑜伽行派よりも偉大な中を説く中観派の立場を 指しているにすぎないと考えられよう。

1）木村 2016: 注 32 に，これまでの Atiśa 研究が詳細に手際よくまとめられているので, 参照されたい，拙稿では特に Miyazaki 2007, 宮崎 2009, 2012 が関係する.

2）例えば, 'Jam dbyañs bźad pa 著『大宗義書』（Grub mtha'chen mo）に, Atiśa が州謬論 証派に分類されることなどが挙げられよう。 Mimaki 1982: 29-30 等参照.

3）Atiśa が実践的な性格の強い Candrakīrti や Śantideva を評価し, 実践を中心として仏 教の総合的な体系を構築したことは以前から指摘されてきた. 江島 1980: 246-248 等.

4）宮崎 2008: (122)-(124)において, 『細注』だけでは理解できないような形でテキスト が伝承されている場合があることを指摘した.

5）注 1 に挙げた木村 2016: 注 32 参照.

6）松本 $1982 \mathrm{a}$ ならびに生井 1990 参照.

7） Ratnakarandodghāta (D 104b1-4) 31-32 ならびに91-92 を参照されたい.

8）チベット大蔵経諸版にはここに文の区切り（śad）がなく，これまでの諸現代語訳も ここで区切らない. しかし，そのままでは読みにくいと思われるため，『細注』の他の 用例もふまえ，このように訳す， BMDP, D 259a3, P 298b4-5 と比較されたい.

9）『菩提道灯細注』のテキストには否定辞がないが, 引用元の『菩薩律儀二十頌細注』 のテキスト（Bodhisattvasaṃvaravimiśaka-pañjikā, D 186b4-6, P 215a8-b2）に基づき，否 定辞を補って理解する.

10）チベット語テキストには「より堅固にしたならば」の後に 'di ltarがあり,「大乗の器 でない者は」以降を引用と考えるのが自然であるため, これまでの諸現代語訳もその ように理解している。しかしながら，文字通りこのままの引用が見付からなかったの で，ひとまず確実に経典の引用がある「de bźin gśegs pa’i sñin po can no」（tathāgatagarbhāḥ）のみを引用と考えている. 
11) Tattvaratnāvalī, 16. sarvabuddhā (sic read sarve buddhā) bhavișyanti nâbhavyo bhūvi (sic read bhuvi) vidyate / na karttavyo 'vasādo 'smāt samyak-sambodhi-sādhane //

12) Sarvatathāgatatattvasamgraha, 86.

13）『四百論』のこの偈頌は, Candrakīrti 著『明句論』にも引かれる（Prasannapadā ad XVIII-8, 370)。丹治 1988: 264-265 も参照.

14）三つの有情のグループ（sattva-rāśi） と山（rdo, śaila. あるいは石）の喻えは，どちら も幾つか可能性が考えられるが, この短い一節から断定するのは難しい.

15）声聞種性, 独覚種性, 菩薩（如来）種性, 不定種性, 無種性のいわゆる五性.

16）Atiśa の師の一人である Suvarṇadvīpa（Dharmakīrti）には, Durbodhāloka と題する『現 観荘厳論』に対する註釈（D 3794, P 5192）が残るが，その中にこの一節は見当たらな い. 法性種性と習所成種性という区別は,『菩薩地』や『宝性論』などにも出る prakrtisthagotra と samudānīta-gotra が対応すると思われる. dharmatā-gotra という表現は他に見付 からないが, Haribhadraの著作の中の prakṛtistham anuttara-buddha-dharmāṇām gotram dharmatā-samjñakam という表現が参考になろう。『細注』の直前に引用された『現観荘 厳論』の偈頌も関係するものである. Abhisamayālaṃkārālokāa ad I-37-38, 77.

17） Miyazaki 2007: 77-78. 宮崎 2012 でも注（7）の中で簡単に触れた.

18）『細注』には，他に四箇所「大中」の語が出る，最初の二つをまとめて記すと以下の 通り。（1）D 280a4-7, P 323b4-324a1，（2）D 281a4-5, P 324b7-325a1，（3）D 282b6283a1, P 326b7-327a2．また「大中」の意味の理解は筆者と異なるが, 望月 2006: 88-90 にも全用例がまとめられているので, 参照されたい.

19）注 8 ならびに注 9 に変更点について注記した.

\section{〈一次文献〉}

Abhisamayālaṃkārālokā

$B M D P$

$B P P$

Niraupamyastava

Prasannapadā
Abhisamayālamkāar'ālokē Prajñāpāramitāvyākhyā, the Work of Haribhadra. Ed. Unrai Wogihara. Tokyo: Sankibo Buddhist Book Store, 1973. First published 1932-1935.

Bodhimārgadīpa-pañjikā. D 3948, P 5344.

Bodhipathapradīpa: Ein Lehrgedit des Atiśa (Dīpamkaraśrījñ̄āa) in der tibetischen Überlieferung. Ed. Helmut Eimer. Asiatische Forschungen 59. Wiesbaden: Otto Harrassowitz, 1978.

"Two Hymns of the Catuhstava of Nāgārjuna." Ed. Giuseppe Tucci. Journal of the Royal Asiatic Society of Great Britain and Ireland 64 (1932): 309-325.

Mūlamadhyamakakārikās (Madhyamikasūtras) de Nāgārjuna avec la Prasannapadā Commentaire de Candrakīti. Ed. Louis de la Vallée Poussin. Bibliotheca Buddhica 4. Tokyo: Meicho-Fukyu-kai, 1977. First published 19031913. 
Ratnakarandodghāța

Sarvatathāgatatattvasaṃraha

Bodhisattvasamvaraviṇśaka-pañjikā

Tattvaratnāvalī
Ratnakaraṇ̣odghāta-nāma-Madhyamakopadeśa. D 3930, P 5325. 宮崎泉「『中観優婆提舎開宝䈄』テキスト・訳 注」『京都大学文学部研究紀要』46 (2007): 1-126.

Sarvatathāgatatattvasamgraha-nāma-mahāyānasūtra. 堀 内寛仁編著『梵蔵漢対照初会金剛頂経の研究梵文校訂 編（上）——金剛界品・降三世品——密教文化研究 所, 1983.

D 4083, P 5584.

Advayavajrasamgraha. Ed. Mahamahopadhyaya Haraprasad Shastri. Gaekwad's Oriental Series 40. Baroda: Oriental Institute, 1927.

\section{〈参考文献〉}

江島惠教 1980 『中観思想の展開』春秋社.

木村誠司 2016 「悪役クトゥン」『駒澤大学仏教学部研究紀要』74: (59)-(295).

丹治昭義 1988 『沈黙と教説一中観思想研究 1』関西大学東西学術研究所研究叢刊 6 , 同 朋社.

生井智紹 1990「Kamalaśīla の〈一乗思想〉について」『印度学仏教学研究』38 (2): (112)-(117). 松本史朗 1982a「Madhyamakāloka の一乗思想について———乗思想の研究 (I) 一」」『曹 洞宗研究員研究生研究紀要』14: (1)-(47).

—1982b「唯識派の一乗思想について——乗思想の研究（II）—」『駒澤大学仏 教学部論集』13: (1)-(23).

宮崎泉 2008 「アティシャ作『菩提道灯細注』に説かれる律について」『印度学仏教学研

究』56(2): (120)-(125).

— 2009「アティシャの二諦説再考」『印度学仏教学研究』58 (1): (128)-(132).

—2012「アティシャの中観思想」桂紹隆他編『シリーズ大乗仏教 6 空と中観』春秋 社, $137-167$.

望月海慧 2006 「中観と唯識を融合する「大中観」とは何か——仏教思想史における相剋 と融和の一断面」『大崎学報』162: 83-94.

——訳 2015 『全訳アティシャ菩提道灯論』起心書房.

Eimer, Helmut. 1977. Berichte über das Leben des Atiśa (Dīpamkaraśrījñāna). Asiatische Forschungen 51. Wiesbaden: Otto Harrassowitz.

Mimaki, Katsumi. 1982. Blo gsal grub mtha'. Kyoto: Zinbun Kagaku Kenkyusyo, Kyoto University.

Miyazaki Izumi. 2007. "Atiśa (Dīpaṃkaraśrìjñāna)—His Philosophy, Practice and Its Sources."

The Memoirs of the Research Department of the Toyo Bunko 65: 61-89.

〈キーワード〉 アティシャ, 如来蔵, 『菩提道灯細注』, 大中 